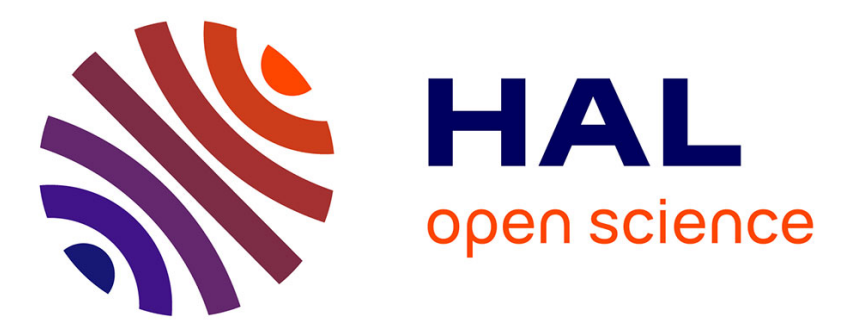

\title{
Annexins from bovine adrenal cortex exhibit specific cytosol/membrane solvation.
}

J. Moufquia, B. Rothhut, D. Rainteau, C. Comera, A. Alfsen, F. Russo-Marie, F. Lavialle

\section{- To cite this version:}

J. Moufquia, B. Rothhut, D. Rainteau, C. Comera, A. Alfsen, et al.. Annexins from bovine adrenal cortex exhibit specific cytosol/membrane solvation.. Biochemical and Biophysical Research Communications, 1993, 195 ((1)), pp.132-8. hal-00815359

\section{HAL Id: hal-00815359 \\ https://hal.science/hal-00815359}

Submitted on 1 Jun 2020

HAL is a multi-disciplinary open access archive for the deposit and dissemination of scientific research documents, whether they are published or not. The documents may come from teaching and research institutions in France or abroad, or from public or private research centers.
L'archive ouverte pluridisciplinaire HAL, est destinée au dépôt et à la diffusion de documents scientifiques de niveau recherche, publiés ou non, émanant des établissements d'enseignement et de recherche français ou étrangers, des laboratoires publics ou privés. 


\section{ANNEXINS FROM BOVINE ADRENAL CORTEX EXHIBTT SPECIFIC CYTOSOL/MEMBRANE SOLVATION}

J. Moufquia, ${ }^{\text {B. Rothhut, }}{ }^{2}$ D. Rainteau, ${ }^{3}$ C. Comera, ${ }^{2}$ A. Alfsen, ${ }^{2}$ F. Russo-Marie, ${ }^{2}$ and F. Lavialle'

${ }^{1}$ Laboratoire des Etats Liés Moléculaires, Université René Descartes, 45 rue des Saints-Pères 75270 Paris Cedex 06, France

2 Unité INSERM 332, ICGM, 22 rue Méchain 75014 Paris, France

${ }^{3}$ Laboratoire des mécanismes de régulations intracellulaires, Université René Descartes, 45 rue des Saints-Pères 75270 Paris Cedex 06, France

Received July 8, 1993

Cytosol/membrane localization of annexins I to $\mathrm{VI}$ was analyzed in tissue extracts from bovine adrenal cortex. Based on their solubility in either aqueous or detergents solutions, they were subfractionated in three groups named cytosolic (C), membrane-bound (MB) and membraneinserted (MI). Less than $1 \%$ of the total annexins present in the tissue were recovered in the C fraction when as much as 76.5 and $22.5 \%$ were obtained respectively in the MB and the MI fractions.

By immunoblotting after SDS-PAGE, it was shown that the various members of the annexin family were not equally recovered in the different fractions. A-V and A.VI were found present in the three fractions whereas the distribution of A-I, A-II, A-III and A-IV was distinct, suggesting different cellular functions.

Annexins belong to a family of structurally related proteins detected in diverse eukaryotic organisms from mammalian to sponge, slime molds and higher plants. They differ slightly across species (1). They possess a core domain composed of a conserved segment of 70-80 amino-acids which is repeated four times in annexins with masses in the 30-50 kDa range and eight times in the $70 \mathrm{kDa}$ annexin (2). Each repeat contains a consensus sequence of 17 amino-acids termed endonexin fold (3). Annexins reversibly bind acidic phospholipids in a calcium dependent manner, which differ with respect to the concentration of $\mathrm{Ca}^{2+}(4,5)$. They coexist in a wide variety of tissues but differ in their relative concentration (6) and in their cellular localization. For example, in endothelial cells, using immunofluorescence and electron microscopy after immunogold labeling, it was shown that A-I was located both in the cytoplasm close to the plasma membrane and inside the nucleus when A-II, A-V and A-VI were detected in these cells almost exclusively in the cytoplasm (7). At the opposite, different members of the annexin family

0006-291X/93 $\$ 4.00$ 
were shown to behave as integral proteins. They require detergent (8-12) or acidic chloroformmethanol (13) for their solubilization and appears as good candidates for the orchestration of membrane events of the cellular traffic $(14,15)$.

As a first step to precise in the adrenal cortex, the possible participation of annexins in the sorting of LDL-receptor complexes, we analyzed the annexin content of the tissue. The respective amount of cytosolic and membrane-associated annexins and the forces which govern these locations were precised. Based on their partition in either ionic or detergents solutions, annexins were subfractionned in three groups named $\mathrm{C}$ for cytosolic, $\mathrm{MB}$ for membrane-bound and $\mathrm{MI}$ for membrane-inserted. In the present study we show that the various annexins have caracteristic cytosol/membrane repartitions, suggesting that these proteins may be involved in different cellular processes and that hydrophobic interactions are an important aspect of the annexin function(s).

\section{MATERIAL AND METHODS}

All reagents were of analytical grade.

\section{Extraction of annexins.}

$150 \mathrm{~g}$ of bovine adreno cortical tissue were scrapped off from 10-15 adrenal glands of freshly slaughtered animals. Homogeneization was performed in 3 volumes $(450 \mathrm{ml})$ of buffer I (10 mM Hepes, $1 \mathrm{mM} \mathrm{NaN}, 2 \mathrm{mM}$ PMSF, $1 \mu \mathrm{g} / \mathrm{ml}$ leupeptin, $1 \mu \mathrm{g} / \mathrm{ml}$ pepstatin, $\mathrm{pH}$ 7.4) using a Waring blender ( $3 \times 15$ seconds). EDTA was omitted in this extraction buffer.

Debris and nuclei were pelleted and removed by centrifugation at $3,000 \mathrm{~g}$ for 10 minutes. The fractions named $C, M B_{1}, M B_{2}, M B_{3}$ and $M 1$ were recovered from $P 1, P 2, P 3$ and $P 4$ (fig.1). These pellets were resuspended with a dounce homogeneizer (pestle B) in buffer II (buffer I +5 mM EDTA), buffer III (buffer II $+150 \mathrm{mM} \mathrm{NaCl}$ ), buffer IV (buffer II $+500 \mathrm{mM} \mathrm{NaCl}$ ) and buffer V (buffer II $+2 \%$ Triton-X100+0.25 mM octylglucoside) respectively. After overnight incubation, the suspensions were centrifuged at $105000 \mathrm{~g}$ for one hour (twice). The supernatants (S0, S1, S2, S3 and S4) were processed for annexin enrichment by addition of $\mathrm{CaCl}_{2}$ to a final molar concentration of $3 \mathrm{mM}$. After overnight incubation the suspensions were centrifuged at $40,000 \mathrm{~g}$ for 30 minutes. Pellets were washed twice with (buffer I $+150 \mathrm{mM} \mathrm{NaCl}+\mathrm{CaCl}_{2}$ $5 \mathrm{mM}$ ) and resuspended with $10 \mathrm{ml}$ of (buffer I $+10 \mathrm{mM}$ EGTA). After overnight incubation, the suspensions were centrifuged at $105,000 \mathrm{~g}$ for one hour. The supernatants were respectively named $\mathrm{C}, \mathrm{MB}_{1}, \mathrm{MB}_{2}, \mathrm{MB}_{3}$ and $\mathrm{MI}$.

\section{Identification of annexins.}

The different fractions $\left(C, M B_{1}, M B_{2}, M B_{3}\right.$ and $\left.M I\right)$, were analyzed by SDS-PAGE (12\% acrylamide) according to Laemmli (16) and transferred by the semi-dry procedure (10 $\mathrm{mA}$ per $\mathrm{cm}^{2}$ for 45 minutes) onto a nitrocellulose sheet. Rabbit polyclonal antibodies against A-I, A-III, $A-V$ and $A-V I$ purified from human placenta, were prepared by popliteal lymph mode injection according to Goudie et al (17). The anti-A-II serum was a gift from J.C Cavadore (Montpellier). The anti-A-IV serum was kindly provided by $\mathrm{C}$. Creutz (Charlottesville, Va USA). The different anti-sera were used at a dilution 1:2000. The proteins were visualized using horseradish peroxidase-conjugated goat anti-rabbit IgG and 4-chloro-1-naphtol as substrate.

In all fractions, the major polypeptides detected by Coomassie blue staining were identified as members of the annexin family. The protein content of each fraction - determined by the method of Peterson (18) - was thus considered as corresponding to the annexin content. It was expressed 
in \% using $100 \%$ as the amount of annexins present in $\left(\mathrm{C}+\mathrm{Mb_{1 }}+\mathrm{Mb_{2 }}+\mathrm{Mb_{3 }}+\mathrm{MI}\right)$.

The 2-dimensional (2-D) electrophoretic analysis was performed according to O'Farrell (19).

All the experiments were performed in triplicate.

\section{RESULTS AND DISCUSSION}

Cytosol-Annexins interactions. (C fraction).

The cytosolic fraction (so-called $\mathrm{C}$ fraction) was recovered after tissue homogeneization in buffer I, which contains neither EDTA nor $\mathrm{NaCl}$ (fig. 1). Few polypeptides were detected by Coomassie blue staining (fig. 2A). The immunoblotting data presented in figure $2 \mathrm{~B}$ indicate that $\mathrm{A}-\mathrm{V}$ and $\mathrm{A}$ VI are the two members of the annexin family present in this fraction. The annexin content of the $C$ fraction was found close to $150 \mu \mathrm{g}$ i.e less than $1 \%$ of the annexins recovered from the adrenal cortex. From immunocytochemical data, such a cytosolic localization of annexins was often

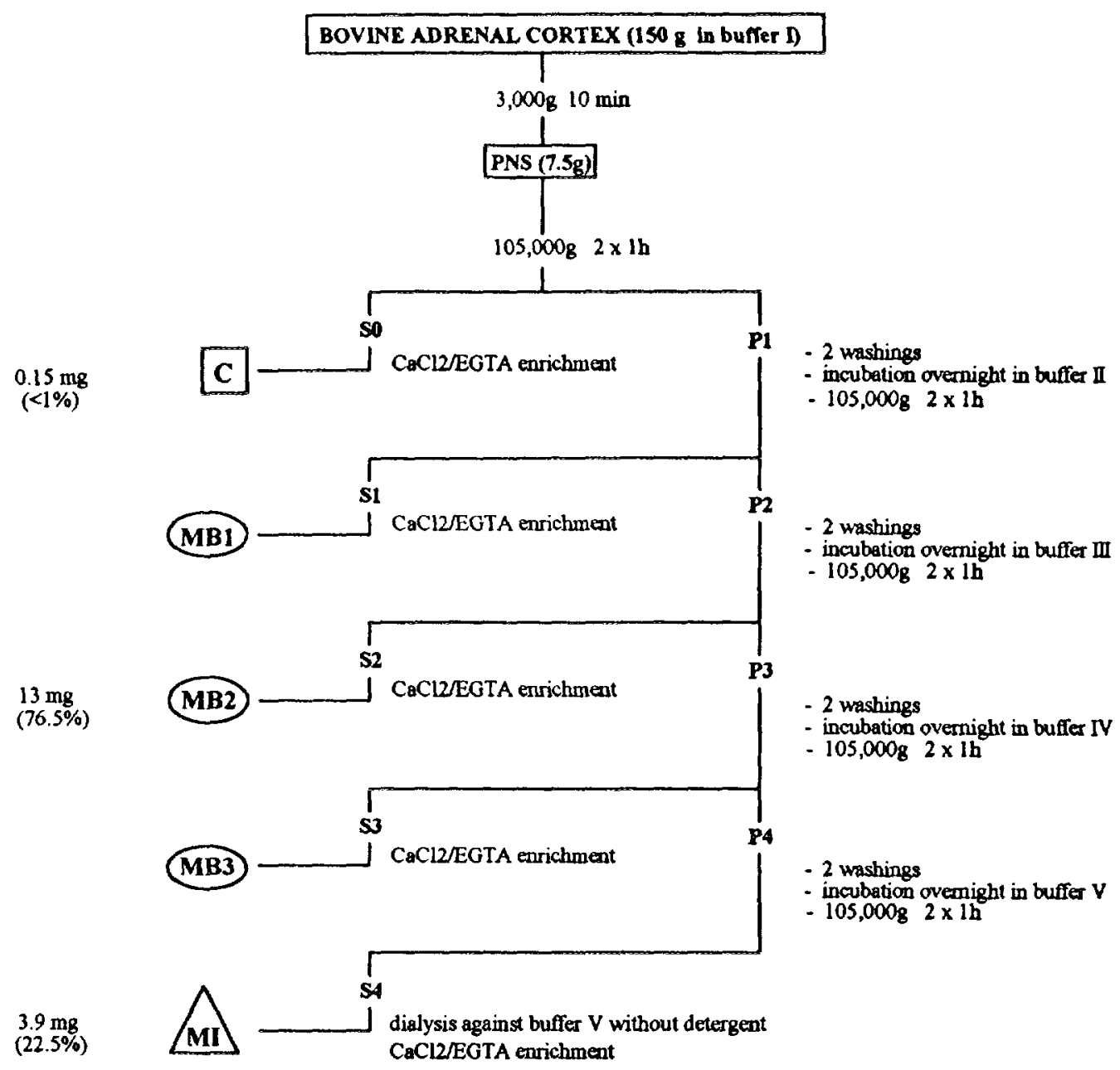

Figure 1.Illustration of the annexins extraction and enrichment. 


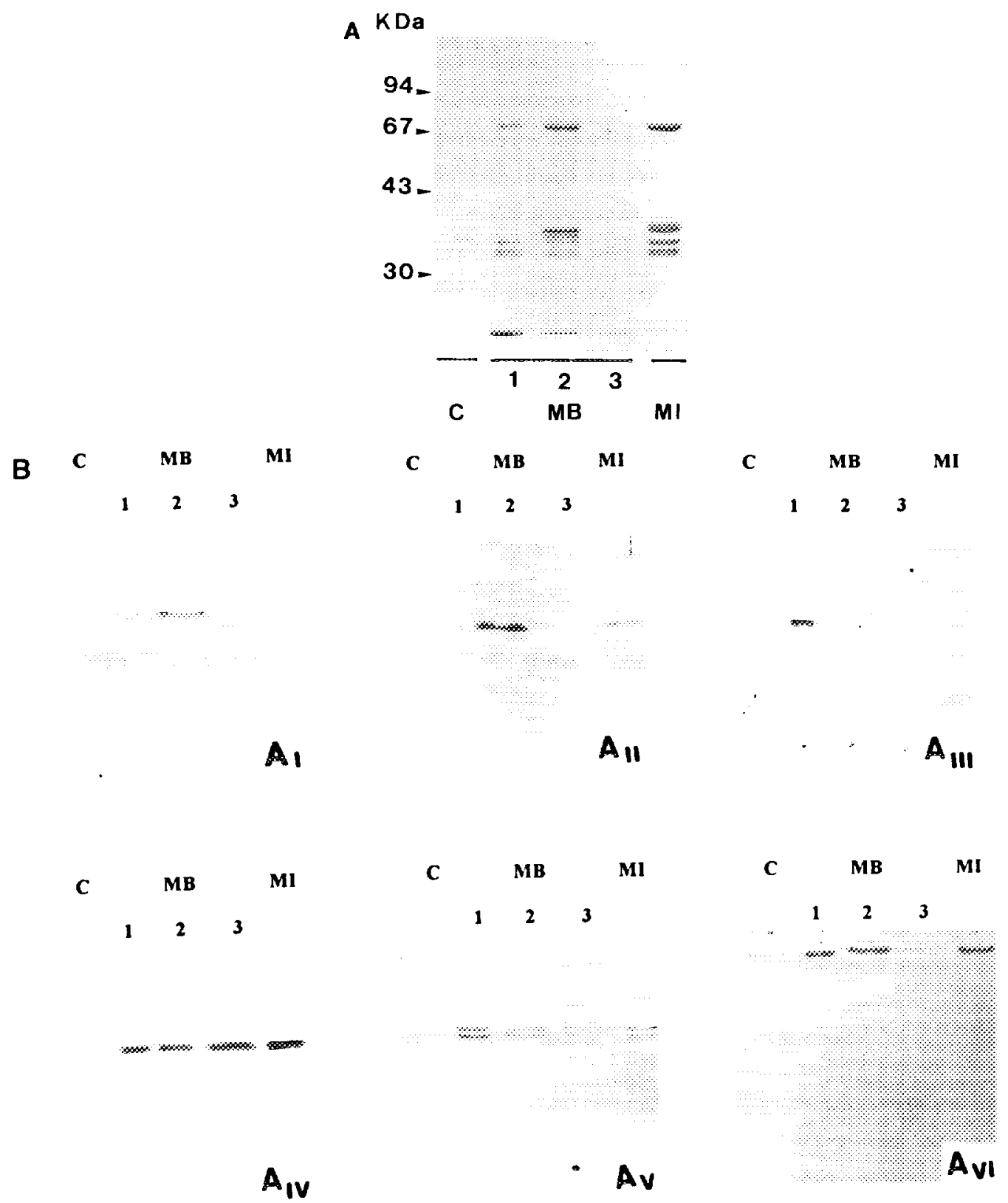

Figure 2.(A): Coomassie Brilliant blue-stained SDS-PAGE of the different annexin-enriched fractions (2 to $5 \mu \mathrm{g}$ per well). (B): Corresponding Westem blots using antibodies to the different annexins A-I to A-VI. C: annexins of the cytosolic compartment, MB: annexins interacting with membranes via electrostatic interactions, MI: annexins interacting with membranes via hydrophobic interactions.

reported. Using monoclonal antibodies raised against A-IV, Massey et al (20) observed an homogeneous labeling in intestinal mucous secreting cells and in centro acinar pancreatic cells. In endothelial cells, antibodies raised against A-II, A-V and A-VI detected these proteins almost exclusively in the cytoplasm (7). 


\section{Lipid head groups-Annexins interactions. (MB fraction).}

As shown on figure 1 , we sequentially solvated the annexins bound to the membranes via $\mathrm{Ca}^{2+}$ $\left(\mathrm{MB}_{1}\right.$ subfraction) and via other ions $\left(\mathrm{MB}_{2}\right.$ and $\mathrm{MB}_{3}$ subfractions). Altogether they contribute to $76.5 \%$ (13 mg) of the annexins recovered in the adrenal cortex homogenate.

The electrophoretic patterns presented in figure $2 \mathrm{~A}$ reveal in the $\mathrm{MB}_{1}$ subfraction the presence of several polypeptides in the $30-50 \mathrm{kDa}$ range and a $70 \mathrm{kDa}$ signal. Figure $2 \mathrm{~B}$ shows that $\mathrm{MB}_{1}$ contains all the annexins searched for (A-I to A-VD). Special attention has to be paid to A-III which is only detected in this subgroup, indicating that $\mathrm{Ca}^{2+}$ is the major cation involved in the membrane-A-III interacting process. The annexin content of this subfraction is found equal to $70 \%$ of the annexins isolated from the adrenal cortex homogenate and $92 \%$ of the total MB annexins content. Their recovery is made possible by conducting the experiments in the presence of EDTA but in the absence of $\mathrm{NaCl}$, an uncommon experimental procedure. The $\mathrm{Ca}^{2+}$. dependent interacting process between annexins and membranes is not yet precised. It is not known how the interaction with other proteins (p10 light chains, calcyclin) and the lipid composition of the membranes may influence the calcium requirement of the annexins. Up to now, the calcium effect has been mainly related to conformational changes underwent by annexins $(21,22)$, when it is well known that $\mathrm{Ca}^{2+}$ affects considerably the dynamics and phase behaviour of anionic lipids by sequestering $\mathrm{H}_{2} \mathrm{O}$ molecules involved in lipid head group hydration $(23,24)$.

Increasing the ionic strength of buffer II led to the disruption of electrostatic interactions not involving $\mathrm{Ca} 2+$. In $\mathrm{MB}_{2}$ which contains the annexins loosely bound to membranes, A-III is the only member of the annexin family search for which is not detected under the present experimental conditions. In $\mathrm{MB}_{3}$, which contains the annexins firmly interacting with the membranes, only A-IV, A-V and A-VI are recovered. Taking into account the procedure used in the present work for annexins extraction (see fig.1), the presence of annexins in $\mathrm{MB}_{2}$ and $\mathrm{MB}_{3}$ subfractions indicates that, in contrast with the data reported in the literature, a significant amount of annexins have the ability to interact with membranes in the absence of calcium. It corresponds to $9.5 \%$ of the annexins present in the adrenal cortex homogenate.

\section{Lipid hydrophobic tails-Annexins interactions. (MI fraction).}

At this step of the procedure, the annexins still present in the $\mathrm{P}_{4}$ pellet were considered as interacting with the hydrophobic domain of the membrane (MI fraction). They were recovered by addition of (2\% Triton X-100 $+25 \mathrm{mM}$ octylglucoside) to buffer II. Figure $2 \mathrm{~B}$ indicates that MI contains A-I, A-II, A-IV, A-V and A-VI. Only A-III is not detected. Protein quantification indicates that the annexins of this fraction represent as much as $22.5 \%$ of the adrenal cortex annexins.

Rather few reports concern the partition of annexins within the hydrophobic core of the membrane. To our knowlegdge, only A-I, A-V and A-VI were reported to be recovered after membrane solubilization by detergents $(8-12,25)$. In matrix vesicles implicated in mineral deposition in cartilage, A-V and A-VI were shown to selectively partition in an acidic organic phase revealing unsuspected proteolipid-like properties (13). This unusual solvation property raises the question of the existence of stable annexin-lipid complexes. 

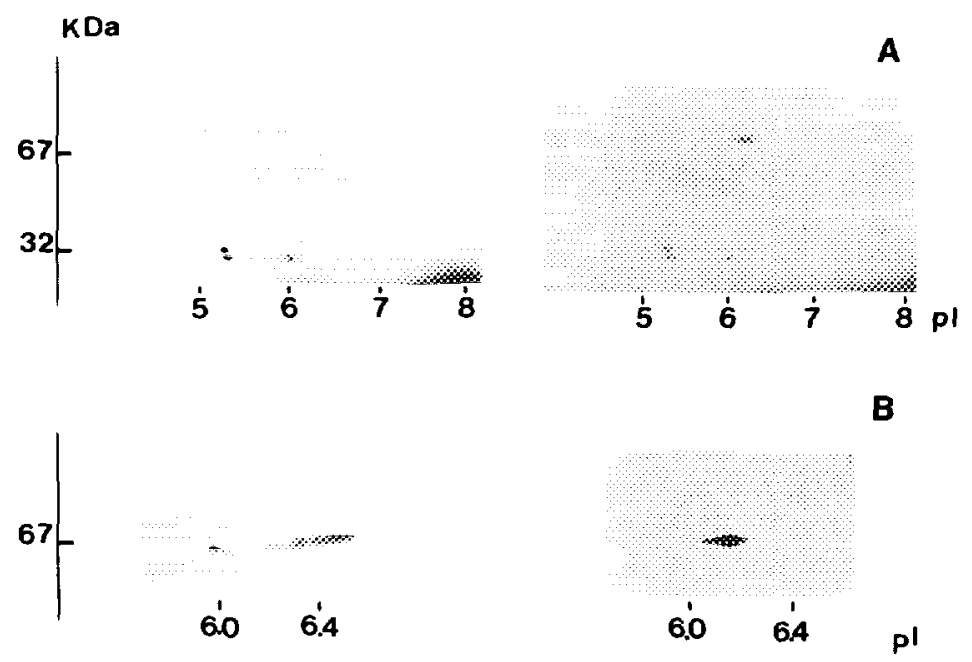

Figure 3.Two dimensional electrophoresis of $\mathrm{MB}_{1}$ (left) and $\mathrm{MI}$ (right) fractions. $8 \mu \mathrm{g}$ of each sample was layered on the gel. (A): Coomassie blue staining; (B): corresponding Western blot using anti-A-VI antibodies.

In conclusion, it appears that the adrenal cortex contains a large amount of annexins: $17 \mathrm{mg}$ are recovered starting from $150 \mathrm{~g}$ of cortex tissue ( $7.5 \mathrm{~g}$ of proteins in the PNS). By using an original experimental procedure of extraction, we identified the annexin content of both the cytosol and the membrane compartments. Quite interestingly, A-V and A-VI are detected in the C, MB and MI fractions. Such different solvation properties could either reflect an heterogeneity at the molecular level or in its three dimensional structure. A first sets of experiments, performed by $2 \mathrm{D}$ electrophoresis and immunoblotting on $\mathrm{MB}$ and $\mathrm{MI}$, clearly showed that the spot attributed to A-VI largely differed depending on the solvation medium (fig.3A and 3B). The population of AVI solvated by the hydrophobic domain of the membranes (MI fraction) appeared more homogeneous than the corresponding molecules interacting with the membranes via electrostatic forces $\left(\mathrm{MB}_{1}\right.$ fraction). This is consistent with structural differences possibly related to posttraductional events that await further studies.

\section{REFERENCES}

1. Moss, S.E. in: The Annexins (MOSS, S.E ed), Portland Press, London.

2. Crumpton, M. R., Moss, S. E. and Crumpton, H. J. (1988) Cell 55, 1-3.

3. Glenney, J. R. (1986) J. Cell Biol. 261, 7247-7252.

4. Blackwood, R. A. and Emst, J. D. (1990) Biochem. J. 266, 195-200.

5. Klee,X.B. (1988) Biochemistry $276645-6653$.

6. Römisch, J., Schüler, E., Bastian, B., Bürger, T., Dunkel, F. - G., Schwinn, A., Hartmann, A. A. and Paques, E. P. (1992) Blood coagulation and fibrinolysis 3, 11-17.

7. Raynal, P., Van Bergen, P., Hullin, F., Ragab-Thomas, J., Fauvel, J., Verkleiij, A. and Chap, H. (1992) Biochem. Biophys. Res. Commun. 186/1, 432-439.

8. Pula, G., Bianchi, R., Ceccarelli, P., Giambianco, I. and Donato, R. (1990) FEBS Lett. 277 1-2, 53-58.

9. Campos-Gonzales, R., Kanemitsu, M. and Boyton, A. L. (1989) Exp. Cell Res. 184, 287-296.

10. Drust, D. S. and Creutz, C. E. (1991) J. Neurochem. 56, 469-478. 
11. Bianchi, R., Giambanco, I. Ceccarelli, P., Pula, G., and Donato, R. (1992) FEBS Lett. 96,158-162.

12. Turgeon, J. L., Cooper, R. H. and Waring, D. W. (1991) Endocrinology 128/1, 96-102.

13. Genge, B. R., Wu, L. N. Y., Adkinson, H. D. and Wuthier, R. E. (1991) J. Biol. Chem. 266, 10678-10695.

14. Fuller, C.E., Felder, S., Schlessinger, J., Ullrich, A. and Hopkins, C.R. (1993) J. Cell. Biol. $20,77-43$.

15. Lin, H.C., Südhof, T.C. and Anderson,R.G.W. (1992) Cell 70, 283-291.

16. Peterson, G. L. (1977) Anal. Biochem. 83, 346-356.

17. Goudie, R.B., Horne, C.H.W. and Wilkinson, P.A. (1966) Lancet II, 1224-1226.

18. Laemmli, U. K. (1970) Nature 277, 680-685.

19. O'Farrell, P. H. (1975) J. Biol. Chem. 250, 4007-4021.

20. Massey, D., Traverso, V., Rigal, A. and Maroux, S. (1991) Biol. Cell. 73, 151-156.

21. Pigault, C., Follenius-Wund, A., Lux, B. and Gerard, D. (1990) Biochim. Biophys. Acta 1037, 106-114.

22. Linse, A., Teleman, O. and Drakenberg, T. (1990) Biochemistry 29, 5925-5934.

23. Livingstone, C. J. and Schachter, D. (1980) Biochemistry 19, 4823-4827.

24. Hoekstra, D. (1982) Biochemistry 21, 2833-2840.

25. Donato, R., Giambanco, I., Pula, G. and Bianchi, R. (1990) FEBS Lett. 262, 72-76. 